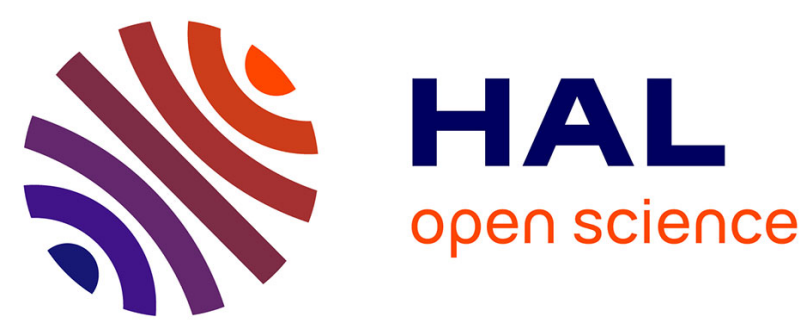

\title{
Defect of villous cytotrophoblast differentiation into syncytiotrophoblast in Down's syndrome.
}

Jean-Louis Frendo, Michel Vidaud, Jean Guibourdenche, Dominique Luton, Françoise Muller, Dominique Bellet, Yves Giovagrandi, Anne

Couturier-Tarrade, Dominique Porquet, Philippe Blot, et al.

\section{To cite this version:}

Jean-Louis Frendo, Michel Vidaud, Jean Guibourdenche, Dominique Luton, Françoise Muller, et al.. Defect of villous cytotrophoblast differentiation into syncytiotrophoblast in Down's syndrome.: TROPHOBLAST AND DOWNS SYNDROME. Journal of Clinical Endocrinology and Metabolism, 2000, 85 (10), pp.3700-7. inserm-00128454

\section{HAL Id: inserm-00128454 https://www.hal.inserm.fr/inserm-00128454}

Submitted on 12 Feb 2007

HAL is a multi-disciplinary open access archive for the deposit and dissemination of scientific research documents, whether they are published or not. The documents may come from teaching and research institutions in France or abroad, or from public or private research centers.
L'archive ouverte pluridisciplinaire HAL, est destinée au dépôt et à la diffusion de documents scientifiques de niveau recherche, publiés ou non, émanant des établissements d'enseignement et de recherche français ou étrangers, des laboratoires publics ou privés. 


\title{
Defect of villous cytotrophoblast differentiation into syncytiotrophoblast in Down syndrome
}

\author{
FRENDO JL ${ }^{1}$, VIDAUD $\mathrm{M}^{2}$, GUIBOURDENCHE $\mathrm{J}^{3}$, LUTON ${ }^{4}$, MULLER $\mathrm{F}^{2}$, \\ BELLET D ${ }^{6}$, GIOVAGRANDI $Y^{2}$, TARRADE A ${ }^{1}$, PORQUET $^{3}$ D, BLOT $^{4}$, EVAIN- \\ BRION D ${ }^{1}$.
}

${ }^{1}$ Institut National de la Santé et de la Recherche Médicale, U427, ${ }^{2}$ Laboratoire de Génétique Moléculaire, ${ }^{6}$ Centre National de la Recherche Scientifique UPRES-A 8067, Faculté des Sciences Pharmaceutiques et Biologiques, Université René Descartes, Paris, France.

${ }^{3}$ Service d'Hormonologie, ${ }^{4}$ Service de Gynécologie Obstétrique, Hôpital Robert Debré, Paris, France.

${ }^{5}$ Service de Biochimie, Hôpital Ambroise Paré, Boulogne, France.

Correspondence should be addressed to Dr D. EVAIN-BRION:

INSERM U427

Faculté des Sciences Pharmaceutiques et Biologiques

4, avenue de l'observatoire

75270 Paris cedex 06 France.

phone: 33-1-44-07-39-91; fax: 33-1-44-07-39-92

email: evain@pharmacie.univ-paris5.fr

Running title: Trophoblast and Down syndrome

Key words: Trisomy 21, placenta, differentiation, cell fusion, hormones, hormonal markers 


\section{SUMMARY}

The syncytiotrophoblast (ST) is one of the major components of the human placenta as it is involved in feto-maternal exchanges and the secretion of pregnancy-specific hormones. The aim of this study was to elucidate the formation and function of the ST in trisomy 21 (Down syndrome). We first used the in vitro model of cytotrophoblast differentiation into ST. Cytotrophoblasts were isolated from 15 trisomy 21-affected placentas (12-35 weeks of gestation) and 10 gestational age-matched control placentas. In vitro cytotrophoblasts isolated from normal placenta fused to form the ST. This was associated with an increase in the transcript levels and the secretion of human chorionic gonadotropin (hCG), human placental lactogen (hPL), placental growth hormone (PGH) and leptin. In trisomy 21-affected placentas, we observed a defect (or a delay) in ST formation and a dramatic decrease in the synthesis and secretion of these hormones as compared to cultured cells isolated from control age-matched placentas. These results were confirmed by a significant $(\mathrm{p}<0.001)$ decrease in gene expression in total homogenates of trisomy 21-affected placentas as compared to control. These results will be of help in understanding the maternal hormonal markers of fetal trisomy 21 and the consequences of placental defects for fetal development. 


\section{INTRODUCTION}

Trisomy of chromosome 21 (T21), which causes the phenotype known as Down syndrome, is the major known genetic cause of mental retardation and is found in around 1:800 live births. Screening strategies to identify women at increased risk of bearing a T21fetus are based on maternal age, ultrasound signs $(1,2)$ or maternal serum markers (3-6). Some of these markers, such as hCG (4-6), are of placental origin. It is not known why maternal serum hCG is elevated in T21- affected pregnancies.

In human placenta, the syncytiotrophoblast, which forms the outer layer of the chorionic villi, is an active endocrine unit and secretes its hormonal products into the maternal circulation. Some of these polypeptide hormones are specific to pregnancy, such as human chorionic gonadotropin (hCG), human placental lactogen (hPL) and placental growth hormone (PGH) (7-9) and can be used as markers of syncytium formation. The syncytiotrophoblast arises in vitro $(10,11)$ and in vivo (12) from differentiation of villous cytotrophoblasts. These cells aggregate and fuse to form multinucleated syncytiotrophoblasts. The morphological and functional differentiation of cytotrophoblasts into syncytiotrophoblasts can be induced or inhibited by different factors such as cyclic AMP (13), growth factors like EGF (14) and TGF $\beta$ (15), polypeptide or steroid hormones such as hCG $(16,17)$ and dexamethasone (18), and oxygen tension $(19,20)$.

Despite the fact that some maternal serum markers of fetal T21 are of placental origin, little is known of placental defects in Down syndrome. Therefore, the aim of this work was to study trophoblast differentiation and endocrine functions in Down syndrome. 


\section{METHODS}

Placental tissue collection. French law allows termination of pregnancy with no gestational age limit when severe fetal abnormalities are observed. Samples of placental tissues were collected at the time of termination of pregnancy at 12-35 weeks of gestation (expressed in weeks of amenorrhea) in T21-affected pregnancies and gestational age-matched control cases. Details of history of all T21 and control cases are given in Table I. Gestational age was confirmed by ultrasound measurement of crown-rump length at 8-12 weeks of gestation. Fetal Down syndrome was diagnosed by karyotyping of amniotic fluid cells, chorionic villi or fetal blood cells. We checked that placental tissue was T21-affected by determination of DNA polymorphism markers (21). In no case was T21 due to translocation and no mosaicism was observed. Termination of pregnancy was performed in control cases affected by severe bilateral or low obstructive uropathy or major cardiac abnormalities. Fetal karyotype was normal in all controls. Placental samples were used for cytotrophoblast isolation or immediately frozen in liquid nitrogen.

RNA isolation and analysis. Total RNA was extracted from frozen placental samples by means of the single-step guanidinium-phenol-chloroform method described by Chomczynski and Sacchi (22) and from cultured cells following the procedure of Qiagen (Courtabeuf, France). Total RNA concentration was determined at $260 \mathrm{~nm}$ and its integrity was monitored by $1 \%$ agarose gel electrophoresis. Relative mRNA levels of the different genes were measured with the TaqMan5' nuclease fluorogenic quantitative PCR assay essentially as previously described (23). The nucleotide sequences of the primers and probes are listed in table II. Each sample was analyzed in duplicate and a calibration curve was run in parallel for each analysis. The level of transcripts of the constitutive housekeeping gene product 
cyclophilin A was quantitatively measured in each sample to control for sample-to-sample differences in RNA concentration and quality. The PCR data are thus reported as the number of transcripts per number of cyclophilin A molecules.

Cell culture. Villous tissue was dissected free of membranes, rinsed and minced in $\mathrm{Ca}^{2+}$, $\mathrm{Mg}^{2+}{ }_{-}$free Hank's balanced salt solution. Cytotrophoblasts were isolated after trypsin-DNase digestion and discontinuous Percoll gradient fractionation, using a slight modification of the method of Kliman and Alsat. $(10,11)$ and was adapted for second-trimester placentas. The villous sample was submitted to sequential enzymatic digestions, in a solution which contains $0.5 \%$ of powder trypsin (W/V, Difco), $5 \mathrm{IU} / \mathrm{ml}$ of DNAse I, $25 \mathrm{mM}$ HEPES, $4.2 \mathrm{mM} \mathrm{MgSO} 4$ and $1 \%(\mathrm{~W} / \mathrm{V})$ penicillin/ streptomycin (Biochemical Industry, Israel) in HBSS and monitored under light microscopy. The first and/or second digestion were discarded after light microscopy analysis in order to eliminate syncytiotrophoblast fragments and the following four or five sequential digestions were kept. The cells collected during these last digestions were purified on a discontinuous gradient of Percoll (5 to $70 \%$ in 5\% step). The cells that migrated to the middle layer (density $1.048-1.062 \mathrm{~g} / \mathrm{ml}$ ) were plated on culture dishes $\left(10^{6}\right.$ cells $\left./ \mathrm{cm}^{2}\right)$, attached to the dishes and 3 hours after plating were carefully washed by three washes with culture medium. Following this procedure, we checked that at 3 hours of culture, $90 \%-95 \%$ of the cells isolated from normal or T21 placentas were cytokeratin 7positive using a specific monoclonal antibody (dilution 1:200, Dako, France), less than 0.5\% were vimentin- positive (dilution 1:200, Amersham International), and the other cells were mononucleated and identifed as macrophages. None of these cells were hPL-positive using a polyclonal specific antibody (dilution 1:500, Dako).

Cells were plated in triplicate either on glass slides for immunocytochemistry or onto $60 \mathrm{~mm}$ culture dishes $\left(10^{6}\right.$ cells $\left./ \mathrm{cm}^{2}\right)$. They were cultured for 3 days as previously described (11). 
Cell staining. To detect desmoplakin or E-cadherin, cytokeratin 7 or hPL, cultured cells were rinsed with PBS, fixed, and permeabilized in methanol at $-20{ }^{\circ} \mathrm{C}$, for $25 \mathrm{~min}$. A monoclonal antidesmoplakin or E-cadherin antibody (1:400, Sigma, St Quentin Fallavier, France) or antihPL (1:500, Dako) or a polyclonal anticytokeratin 7 (1:200, Dako) were then applied, followed by fluorescein isothiocyanate-labeled goat anti-mouse immunoglobulin (Sigma), as previously described (19).

Immunoblotting. To detect hPL, cell extracts were prepared as previously described (19) and solubilized protein $(5 \mu \mathrm{g})$ was immunoblotted using a rabbit polyclonal antibody against hPL (1:250, Dako, France) and the specific band was revealed by chemiluminescence (Pierce supersignal, Interchim France) after incubation with an anti-rabbit peroxidase-coupled antibody (19).

Hormone assay. hCG concentration was determined in culture media by an enzyme-linked fluorescence assay (Vidas System, BioMerieux, Marcy l'Etoile, France). Assay sensitivity was $2 \mathrm{mU} / \mathrm{ml}$. hPL concentration was assayed (Amerlex IRMA, Amersham) in maternal serum and in four-fold concentrated conditioned media. Assay sensitivity was $0.5 \mu \mathrm{g} / \mathrm{ml}$. Leptin was determined in four-fold concentrated conditioned media using the Sensitive Human Leptin RIA kit (Linco, St Louis USA). Assay sensitivity was $0.05 \mathrm{ng} / \mathrm{ml}$. All values are means \pm SEM of triplicate determinations.

Protein determination. Protein was determined according to Bradford's method (BioRad kit, France) using bovine serum albumin as standard. 
Statistical tests. Statistical analysis was performed using the StatView F-4.5 software package (Abacus Concepts, Inc., Berkeley, CA, USA). Values are presented as mean \pm SEM. Significant differences were identified using Mann-Whitney analysis for hormonal secretions and ANOVA for transfections; $\mathrm{p}<0.05$ was considered significant. 


\section{RESULTS}

\section{In vitro morphological cytotrophoblast differentiation in Trisomy 21}

Isolated cytotrophoblasts from normal placenta aggregate and fuse in vitro within 48 to 72 hours to form a syncytiotrophoblast $(10,11,13)$. This is indicated by a gathering of nuclei in a large cytoplasmic mass. In the present study, these results were confirmed in 10 different primary cultures of cytotrophoblasts isolated from 10 normal placentas.

In contrast, cytotrophoblasts isolated from 15 different T21-affected placentas had the same plating efficiency as controls, aggregated, but did not fuse or fused poorly. After three days of culture, syncytiotrophoblasts were rare as indicated by immunodetection of desmoplakin (a desmosomal plaque protein) (Fig 1) and of E-cadherin (a cell adhesion molecule) (data not shown). Indeed, desmoplakin and E-cadherin were absent from normal syncytiotrophoblasts as previously shown (19), but present at intercellular boundaries in cultured cells isolated from T21-affected placentas. This illustrates a decrease and/or delay in syncytial formation in $\mathrm{T} 21$.

\section{Failure of functional differentiation of cultured cytotrophoblasts in Trisomy 21}

In cells isolated from normal placenta, in vitro syncytiotrophoblast formation was associated with large increases in hCG $\alpha$ mRNA, hCG $\beta$ mRNA (Fig. 2), hPL mRNA (Fig.3), leptin mRNA and PGH mRNA (Fig 4). Concomitantly, hCG (Fig.2), hPL (Fig.3) and leptin (Fig.4) secretion in culture medium increased with time. In cells isolated from T21-affected placentas, the defect in syncytiotrophoblast formation was associated with a clear decrease in hCG $\alpha$, hCG $\beta$ mRNA and hCG secretion in culture medium (Fig.2), as compared to normal cells. Human PL, leptin and PGH mRNA levels were very low. Human PL and leptin secretion could not be detected in culture medium after 3 days. Intracellular hPL was not 
detected in T21-affected cells in contrast to normal cells. Because glucose inhibits secretion of placental GH (24), this hormone was not assayed in culture medium.

These results suggest that the defect and/or delay in morphological differentiation into syncytiotrophoblast of cytotrophoblasts isolated from T21-placenta, was associated with a decrease in both expression and secretion of hormones specifically synthesized in the syncytiotrophoblast.

mRNA expression of syncytiotrophoblast hormonal markers in normal and T21affected placentas.

In order to confirm these in vitro data, we compared in total homogenates of eight T21affected placentas and eight gestational age-matched controls (12-35 weeks) transcript levels of these hormones specifically expressed in the syncytiotrophoblast. As shown in Figure 5, although levels of the five transcripts varied greatly from one normal placenta to another, the expression of these five genes was significantly lower in T21-affected placenta. Placental samples were homogeneous since no significant differences versus controls were noted in cytokeratin 7 mRNA (specifically expressed in the epithelial component of the chorionic villi, ie the cytosyncytiotrophoblast), in pleiotropin (trophoblastic growth factor) or in $\beta 2$ microglobulin levels (ubiquitous gene) (Fig.6).

These results suggest a decrease in functional syncytiotrophoblast mass in T21-affected placenta.

\section{Human placental lactogen levels in maternal circulation in T21-affected pregnancy.}

During pregnancy, massive amounts of hPL are synthesized by the syncytiotrophoblast and secreted directly into the maternal circulation (8). We therefore checked whether the defect in functional syncytiotrophoblasts in T21- affected placentas was associated with a decreased 
level of hPL in the maternal circulation. As shown in Figure 7, we confirmed that hPL levels were lower in pregnancies with fetal T21 from 14 to 26 weeks of gestation. 


\section{DISCUSSION}

The human placenta is hemomonochorial and is specific in its structure and endocrine functions. One of its major components is the syncytiotrophoblast, at the surface of the chorionic villi, which bathes directly in the maternal blood and arrives in the intervillous space through the uterine spiral arteries. The highly polarized syncytiotrophoblast secretes its hormonal products into the maternal circulation with almost no storage capacity. Any alteration in syncytiotrophoblast formation and/or function should therefore be reflected in the maternal circulation by changes in the levels of syncytiotrophoblast-secreted hormones.

In the present study, we checked that the fetus and placenta were both T21-affected. Cytotrophoblasts isolated from normal and T21-affected placentas were cultured. We confirmed that in vitro normal cytotrophoblasts aggregate and fuse to form the syncytiotrophoblast $(10,11)$. This syncytiotrophoblast formation was associated with an increased secretion in culture medium of hCG (7), hPL (8), PGH (9) and leptin (25) as previously shown. We demonstrate in this study that transcript levels of these hormones also increased with cytotrophoblast differentiation. In trisomy 21, cytotrophoblasts adhered to culture dishes, aggregated but did not fuse (or fused poorly), as observed by light microscopy, confirming the preliminary observations of Eldar-Geva et al. (26), and as demonstrated here by the expression of E-cadherin and desmoplakin. These results are in agreement with previous macroscopic and histological observations of T21-affected placentas which reveal delayed maturation of chorionic villi and syncytiotrophoblastic hypoplasia with a resistant cytotrophoblastic layer in the third trimester $(27,28)$.

This decrease in the syncytiotrophoblast functional mass in T21 placentas is further suggested by the results obtained in homogenates of placental tissues. Indeed, we measured concomitantly by real-time quantitative RT-PCR the expression of the five hormonal genes 
specifically expressed in the syncytiotrophoblast and encoding hormones secreted in the maternal circulation. In normal placenta, a large variation in mRNA expression of syncytiotrophoblast hormones was observed, despite the fact that our sampling was homogeneous as confirmed by cytokeratin 7, pleiotropin and B2-microglobulin expression levels. Despite these variations, mRNA expression of hormones (hCGß, hCG $\alpha, \mathrm{hPL}, \mathrm{PGH}$, leptin) specifically expressed in the syncytiotrophoblast decreased significantly in T21affected placentas.

In this study, we have demonstrated for the first time that in T21-affected placenta there is a defect and/or delay in the formation of the syncytiotrophoblast associated with a decrease in hPL, hCG, PGH and leptin expression and production. These results do not agree with the previous study of Eldar-Geva (26) reporting an increase in hCG $\alpha$ and hCG $\beta$ mRNA in trophoblast cells of T21-affected placenta. This discrepancy may be explained by two facts: 1) Eldar-Geva's study was based on the comparison of one normal and one T21-affected placenta which were not gestational age-matched; 2) the cytotrophoblasts in culture may have been contaminated by fragments of syncytiotrophoblast (29) as hCG secretion diminished instead of increased with time in culture. It is crucial to monitor carefully the isolation and purification of cytotrophoblasts in order to avoid contamination by syncytiotrophoblast fragments. Our method including sequential enzymatic digestion, Percoll gradient purification and careful washing of the cells attached to the dish circumvents this problem. Failure to immunodetect $\mathrm{hPl}$ in the plated isolated cells unambiguously excludes contamination by syncytiotrophoblast fragments.

As anticipated by the results of our in vitro studies, we demonstrated low maternal serum hPL levels in T21-affected pregnancies. Changes in hPL level during gestation showed that the difference between controls and T21-affected pregnancies was not significant between 15 and 18 weeks. This difference became clearer at 19 weeks and increased up to 24 
weeks. This trend paralleled the increase in syncytiotrophoblast mass. These results explain why Ryall et al. observed no differences in maternal serum hPL between 15 and 18 weeks in 48 cases of trisomy 21 (30). In contrast to the results of our in vitro studies, maternal hCG levels are elevated in T21-affected pregnancies $(5,6,31)$. Our study demonstrates a decrease in the synthesis and secretion of hCG in cultured cells from ten T21-affected placentas as well as a decrease in hCG transcripts in eight total placenta extracts in Trisomy 21 . How can we explain this paradox? Maternal levels of hormones of syncytiotrophoblastic origin can be related to transcription but also to the post-translational process, which may modify hormonal stability. hCG is a complex of two glycosylated subunits. In Trisomy 21 , hCG may be subject to post-transcriptional changes as suggested by Brizot et al. $(32,33)$ and recently confirmed by reports of a hyperglycosylated form of hCG in Down syndrome $(34,35)$. This hyperglycosylated form may have a different half-life, thus explaining elevated maternal levels. In contrast, hPL is not glycosylated and the decrease in its synthesis and secretion was directly reflected by a decreased level in the maternal serum after 19 weeks of gestation.

In conclusion, we have demonstrated that: 1) there is an abnormal formation of the syncytiotrophoblast in Down syndrome; 2) there is therefore a decrease in production of pregnancy-specific polypeptide hormones by the placenta in Down syndrome. This finding will enhance understanding of the maternal hormonal changes of placental origin that are used as markers of fetal Down syndrome and will be of help in finding new markers of placental origin. The syncytiotrophoblast plays a key functional role during pregnancy. Better knowledge of its alterations in T21 may therefore be useful in understanding some aspects of fetal development in Down syndrome. 
Acknowledgments: This work was supported by a grant from La Fondation pour la Recherche Médicale (ARS 2000). We thank Dr Fanny Lewin for her support and the staff of Saint Vincent de Paul Obstetrics Department for providing us with placentas. We thank Martine Olivi for her technical assistance. 


\section{REFERENCES}

1. Benacerraf BR. 1996 Use of sonographic markers to determine the risk of down syndrome in second-trimester fetuses. Radiology. 201:619-620.

2. Pandya PP, Snijders RJM, Johnson SP, Brizot M, Nicolaides KH. 1995 Screening for fetal trisomies by maternal age and fetal nuchal translucency thickness at 10 to 14 weeks of gestation. Brit J Obstet Gynaec. 102:957-962.

3. Merkatz I, Nitowsky H, Macri J, Johnson W. 1984 An association between low maternal serum alpha-fetoprotein and fetal chromosomal abnormalities. Am J Obstet Gynecol. 148:886-894.

4. Bogart M, Pandian M, Jones O. 1987 Abnormal maternal serum chorionic gonadotropin levels in pregnancies with fetal chromosome abnormalities. Prenat Diagn. 7:623-630.

5. Wald NJ, Cuckle HS, Densem JW. 1988 Maternal serum unconjugated oestriol as an antenatal screening test for Down's syndrome. Br J Obstet Gynaecol. 95:334-341.

6. Wald NJ, Watt H, Hackshaw A. 1999 Integrated screening for Down's syndrome based on tests performed during the first and second trimesters. N Engl J Med. 341:461-467.

7. Jameson J, Hollenberg A. 1993 Regulation of chorionic gonadotropin gene expression. Endocr Rev. 14:203-221.

8. Handwerger S. 1991 The physiology of placental lactogen in human pregnancy. Endocrinol. 12:329-336.

9. Alsat E, Guibourdenche J, Luton D, Frankenne F, Evain-Brion D. 1997 Human placental growth hormone. Am J Obstet Gynecol. 177:1526-1534. 
10. Kliman H, Nestler J, Sermasi E, Sanger J, Strauss J. 1986 Purification, characterization, and in vitro differentiation of cytotrophoblasts from human term placentae. Endocrinology. 118:1567-1582.

11. Alsat E, Mirlesse V, Fondacci C, Dodeur M, Evain-Brion D. 1991 Parathyroid hormone increases epidermal growth factor receptors in cultured human trophoblastic cells from early and term placenta. J Clin Endocrinol Metab. 73:288-94.

12. Kaufmann P, Scheffen I. 1990 Placental development.. In Polin R, Fox W, eds Neonatal and fetal medicine-physilogy and pathophysiology. Orlando: Saunders.

13. Keryer G, Alsat E, Tasken K, Evain-Brion D. 1998 Cyclic AMP-dependent protein kinases and human trophoblast cell differentiation in vitro. J Cell Sci. 111:995-1004.

14. Morrish D, Bhardwaj D, Dabbagh L, Marusyk H, Siy O. 1987 Epidermal growth factor induces differentiation and secretion of human chorionic gonadotropin and placental lactogen in normal human placenta. J Clin Endocrinol Metab. 65:1282-1290.

15. Morrish D, Bhardwaj D, Paras M. 1991 Transforming growth factor beta 1 inhibits placental differentiation and human chorionic gonadotropin and human placental lactogen secretion. Endocrinology. 129:22-26.

16. Shi QJ, Lei ZM, Rao CV, Lin J. 1993 Novel role of human chorionic gonadotropin in differentiation of human cytotrophoblasts. Endocrinology. 132:1387-1395.

17. Cronier L, Bastide B, Herve JC, Deleze J, Malassine A. 1994 Gap junctional communication during human trophoblast differentiation: influence of human chorionic gonadotropin. Endocrinology. 135:402-408.

18. Cronier L, Alsat E, Hervé JC, Delèze J, Malassiné A. 1998 Dexamethasone stimulates Gap junctional communication peptide hormone production and differentiation in human term trophoblast. Trophoblast Research. 11:35-49. 
19. Alsat E, Wyplosz P, Malassiné A, et al. 1996 Hypoxia impairs cell fusion and differentiation process in human cytotrophoblast, in vitro. J Cell Physiol. 168:346-353.

20. Esterman A, Greco MA, Mitani Y, Finlay TH, Ismail-Beigi F, Dancis L. 1997 The effect of hypoxia on human trophoblast in culture: morphology, glucose transport and metabolism. Placenta. 18:129-136.

21. Muller F, Rebiffe M, Taillandier A, Oury JF, Mornet E. 2000 Parental origin of the extrachromosome in prenatally fetal trisomy 21. New Engl J Med. 324:872-876.

22. Chomczynski P, Sacchi N. 1987 Single-step method of RNA isolation by acid guanidinium thiocyanate-phenol chloroform extraction. Human Genet. 106:340-344.

23. Gibson UE, Heid CA, Williams PM. 1996 A novel method for real time quantitative RT-PCR. Genome Res. 6:995-1001.

24. Patel N, Alsat E, Igout A, et al. 1995 Glucose inhibits human placental GH secretion, in vitro. J Clin Endocrinol Metab. 80:1743-1746.

25. Masuzaki H, Ogawa Y, Sagawa N, et al. 1997 Nonadipose tissue production of leptin: leptin as a novel placenta-derived hormone in humans. Nat Med. 1997:1029-1033.

26. Eldar-Geva T, Hochberg A, deGroot N, Weinstein D. 1995 High maternal serum chorionic gonadotropin level in Downs' syndrome pregnancies is caused by elevation of both subunits messenger ribonucleic acid level in trophoblasts. J Clin Endocrinol Metab. 80:3528-3531.

27. Oberweiss D, Gillerot Y, Koulischer L, Hustin J, Philippe E. 1983 Le placenta des Trisomie 21 dans le dernier trimestre de la gestation. J Gynecol Obstet Biol Reprod. 12:345-349.

28. Benirschke K, Kaufmann P. 1990 Basic structure of the villous tree. In:Benirschke K,Kaufmann P, eds. ed. New York; 22-70. 
29. Huppertz B, Frank H, Reister F, Kingdom J, Korr H, Kaufmann P. 1999 Apoptosis cascade progresses during turnover of human trophoblast: analysis of villous cytotrophoblast and syncytial fragments in vitro. Lab Invest. 79:1687-1702.

30. Ryall R, Staples A, Robertson E, Pollard A. 1992 Improved performance in a prenatal screening programme for Down's syndrome incorporating serum-free hCG subunit analyses. Prenat. Diagn. 12:251-261.

31. Muller F, Aegerter p, Boue A. 1993 Prospective maternal serum hCG screening for the risk of fetal chromosome anomalies and subsequent fetal and neonatal death. Prenat. Diagn. 13:29-43.

32. Brizot M, Jauniaux E, Mckie A, Farzaneh F, Nicolaides K. 1995 Placental expression of alpha and beta subunits of human chorionic gonadotrophin in early pregnancies with Down's syndrome. Hum Reprod. 10:2506-2509.

33. Brizot M, Hyett J, Mckie A, Bersinger N, Farzaneh F, Nicolaides K. 1996 Gene expression of human pregnancy-associated plasma protein-A in placenta from trisomic pregnancies. Placenta. 17:33-36.

34. Cole L. 1998 hCG, its free subunits and its metabolites. Roles in pregnancy and trophoblastic disease. J Reprod Med. 43:3-10.

35. Cole L, Omrani A, Cermik D, Bahado Singh R, Mahoney M. 1998 Hyperglycosylated hCG, a potential alternative to hCG in Down syndrome screening. Prenat Diagn. 18:926933. 


\section{LEGENDS}

Table I: Clinical histories of each control (panel A) and T21-affected (panel B) case. TOP: Termination of pregnancy; AVC: Atrioventricular communication; IVC: Interventricular communication.

Table II: Characteristics of the PCR assays used in this study.

Figure 1: Desmoplakin immunodetection after three days of culture of trophoblast cells isolated from normal placenta (A) and trisomy 21-affected placenta (B). Positive immunofluorescence staining is only observed in cytotrophoblasts that are in contact with the syncytiotrophoblast; staining has disappeared in the fused syncytiotrophoblast. In cells isolated from trisomy 21-affected placenta, desmoplakin staining is observed at the boundaries between aggregated cytotrophoblasts (X 2200).

Figure 2: Panel A hCG $\alpha$ mRNA and hCG $\beta$ mRNA expression during differentiation of cytotrophoblasts isolated from normal (N) and trisomy 21-affected placentas (T21) and cultured for three days. mRNA data are expressed as the level of each marker mRNA normalized by PPIA (Peptidylprolyl isomerase A also called cyclophilin A, a housekeeping gene product) mRNA.Three culture dishes were pooled for each determination. hCG transcript levels were assayed in duplicate.

hCG secretion in the culture medium expressed in $\mathrm{mIU} / \mathrm{ml}$. The results are expressed as the mean \pm SEM of these 3 culture dishes. $* * *: p \leq 0.001$

The results are from one representative experiment.

Panel B Mean hCG secretion in the culture medium of 8 primary cultures of 8 control placentas $(\mathrm{N})$ and 10 primary cultures from 10 trisomy 21 -affected placentas (T21). The results are expressed as the mean \pm SEM of 3 culture dishes at each time in culture. 
Figure 3: hPL expression, secretion in the culture medium and intracellular levels during differentiation of cytotrophoblasts isolated from normal (N) and trisomy 21-affected placentas (T21) and cultured for three days.

Upper panel: levels of hPL transcripts. Data are expressed as the levels of hPL mRNA normalized by PPIA mRNA.

Middle panel: hPL secretion in the culture medium, expressed in $\mu \mathrm{g} / \mathrm{ml}$. The results are expressed as the mean \pm SEM of these 3 culture dishes. ND: not detected.

Lower panel: intracellular hPL levels as detected by Western blotting using a specific monoclonal antibody.

The figure shows the same experiment as in figure 2.

Figure 4: Leptin expression and secretion, PGH expression during differentiation of cytotrophoblasts isolated from normal (N) and trisomy 21-affected placentas (T21) and cultured for three days..

Upper panel: levels of leptin transcripts. Data are expressed as the level of leptin mRNA normalized by PPIA mRNA.

Middle panel: leptin secretion in the culture medium, expressed in $\mathrm{ng} / \mathrm{ml}$.

Lower panel: levels of PGH transcripts. Data are expressed as the level of PGH mRNA normalized by PPIA mRNA.

The figure shows the same experiment as in figure 2.

Figure 5: Expression of $\mathrm{hPL}, \mathrm{hCG} \alpha, \mathrm{hCG} \beta, \mathrm{PGH}$ and leptin transcripts in normal placentas (N) and in trisomy 21-affected placentas (T 21). Data are expressed as ratios of each marker 
transcript level per PPIA (mean \pm SEM). The 8 normal and gestational age-matched trisomy 21 samples are numbered from 1 to 8 for the purposes of comparison. Number 1: 12 weeks of gestation (wks), 2: 14 wks, 3: 16 wks, 4: 18 wks, 5:20 wks, 6: 23 wks, 7: 25 wks, 8: 35 wks. The $\mathrm{p}$ value indicates a significant difference between normal and trisomy 21 -affected placentas.

Figure 6: Expression of cytokeratin 7, pleiotropin and $\beta 2$ microglobulin transcripts in these same 8 normal placentas $(\mathrm{N})$ and in 8 trisomy 21-affected placentas (T 21). Data are expressed as ratios of each marker transcript level per PPIA transcript (mean \pm SEM). The 8 normal and gestational age-matched trisomy 21 samples are numbered from 1 to 8 for the purposes of comparison. NS indicates a non-significant difference between normal and trisomy 21-affected placentas.

Figure 7: Maternal serum hPL levels (median) during normal pregnancies (0) and T21affected pregnancies ( $\mathbf{\square}$ ). The number of individual assays for each gestational stage is indicated next to each point. $* * *: \mathrm{p}<0.001$. 


\begin{tabular}{cccccc}
\hline ID & $\begin{array}{c}\text { Maternal } \\
\text { age }\end{array}$ & $\begin{array}{c}\text { Ultrasound } \\
\text { findings }\end{array}$ & Karyotype & $\begin{array}{c}\text { Gestational } \\
\text { age at TOP }\end{array}$ & Anatomical findings \\
\hline $\mathbf{2}$ & 25 & normal & $46 \mathrm{XX}$ & 12 & - \\
$\mathbf{3}$ & 31 & normal & $46 \mathrm{XX}$ & 14 & dwarfism \\
$\mathbf{4}$ & 32 & skeletal abnormalities & $46 \mathrm{XX}$ & 16 & polymalformation \\
$\mathbf{5}$ & 28 & hygroma & $46 \mathrm{XX}$ & 18 & polycystic kidney \\
$\mathbf{6}$ & 25 & polycystic kidney & $46 \mathrm{XY}$ & 19 & polycystic kidney \\
$\mathbf{7}$ & 24 & polycystic dysplasia & $46 \mathrm{XY}$ & 20 & polycystic kidney \\
$\mathbf{8}$ & 24 & polycystic dysplasia & $46 \mathrm{XY}$ & 20 & polycystic kidney \\
$\mathbf{9}$ & 24 & polymalformation & $46 \mathrm{XY}$ & 23 & skeletal abnormalities \\
$\mathbf{1 0}$ & 27 & polymalformation & $46 \mathrm{XY}$ & 25 & cardiomyopathy \\
\hline
\end{tabular}

Panel A 


\begin{tabular}{|c|c|c|c|c|c|}
\hline ID & $\begin{array}{c}\text { Maternal } \\
\text { age }\end{array}$ & $\begin{array}{l}\text { Ultrasound } \\
\text { findings }\end{array}$ & Karyotype & $\begin{array}{l}\text { Gestational } \\
\text { age at TOP }\end{array}$ & Anatomical findings \\
\hline 1 & 39 & $\begin{array}{c}\text { abnormal nuchal } \\
\text { translucency }\end{array}$ & $47 X Y$ & 12 & facial dysmorphy \\
\hline 2 & 40 & $\begin{array}{l}\text { abnormal nuchal } \\
\text { translucency }\end{array}$ & $47 X Y$ & 13 & facial dysmorphy \\
\hline 3 & 37 & hygroma & $47 X X$ & 14 & AVC \\
\hline 4 & 41 & normal & $47 X Y$ & 15 & IVC \\
\hline 5 & 26 & $\begin{array}{l}\text { abnormal nuchal } \\
\text { translucency }\end{array}$ & $47 X X$ & 16 & AVC \\
\hline 6 & 32 & $\begin{array}{l}\text { abnormal nuchal } \\
\text { translucency }\end{array}$ & $47 X X$ & 18 & facial dysmorphy \\
\hline 7 & 43 & normal & $47 X Y$ & 19 & facial dysmorphy \\
\hline 8 & 41 & normal & $47 X X$ & 20 & renal malformation \\
\hline 9 & 42 & normal & $47 X X$ & 20 & $\begin{array}{l}\text { facial dysmorphy } \\
\text { renal malformation }\end{array}$ \\
\hline 10 & 43 & normal & $47 X Y$ & 23 & $\begin{array}{l}\text { facial dysmorphy } \\
\text { renal malformation }\end{array}$ \\
\hline 11 & 33 & normal & $47 X Y$ & 23 & facial dysmorphy \\
\hline 12 & 34 & IVC & $47 X Y$ & 24 & $\begin{array}{c}\text { facial dysmorphy } \\
\text { AVC }\end{array}$ \\
\hline 13 & 49 & normal & $47 X X$ & 25 & $\begin{array}{l}\text { facial dysmorphy } \\
\text { renal malformation }\end{array}$ \\
\hline
\end{tabular}




\begin{tabular}{|c|c|c|c|c|}
\hline genes & primers and probes & & $\begin{array}{c}\text { GenBank accession } \\
\text { number }\end{array}$ & proteins \\
\hline CGA & $\begin{array}{c}\text { (+) TCCCACTCCACTAAGGTCCAA } \\
\text { (-) CCCCATTACTGTGACCCTGTT } \\
\text { FAM-CACAGCAAGTGGACTCTGAGGTGACG-TAMRA }\end{array}$ & 106 bp & V00518 & $\mathrm{hCG} \alpha$ \\
\hline CGB & $\begin{array}{c}\text { (+) GCTACTGCCCCACCATGACC } \\
\text { (-) ATGGACTCGAAGCGCACATC } \\
\text { FAM-CCTGCCTCAGGTGGTGTGCAACTACC-TAMRA }\end{array}$ & 94 bp & J00117 & $\mathrm{hCG} \beta$ \\
\hline CSA & $\begin{array}{c}\text { (+) GCATGACTCCCAGACCTCCTT } \\
(-) \text { TGCGGAGCAGCTCTAGATTGG } \\
\text { FAM-TTTCTGTTGCGTTTCCTCCATGTTGG-TAMRA }\end{array}$ & $157 \mathrm{bp}$ & J03071 & hPL \\
\hline GHV & $\begin{array}{c}\text { (+) AGAACCCCCAGACCTCCCT } \\
(-) \text { TGCGGAGCAGCTCTAGGTTAG } \\
\text { FAM-TTTCTGCTGCGTTTTCACCCTGTTG-TAMRA }\end{array}$ & 96 bp & J03071 & PGH \\
\hline LEPTIN & $\begin{array}{c}\text { (+) ACATTTCACACACGCAGTCAGT } \\
\text { (-) CCATCTTGGATAAGGTCAGGAT } \\
\text { FAM-TGGAGCCCAGGAATGAAGTCCAAA-TAMRA }\end{array}$ & $96 \mathrm{bp}$ & U18915 & leptin \\
\hline KRT7 & $\begin{array}{c}\text { (+) GGACATCGAGATCGCCACCT } \\
\text { (-) ACCGCCACTGCTACTGCCA } \\
\text { FAM-TCACGGCTCCCACTCCATCTC-TAMRA }\end{array}$ & $171 \mathrm{bp}$ & X03212 & cytokeratin 7 \\
\hline PTN & $\begin{array}{c}\text { (+) GAGATGTAAGATCCCCTGCAACT } \\
\text { (-) CTCGCTTCAGACTTCCAGTTCT } \\
\text { FAM-AGCAATTTGGCGCGGAGTGCAA-TAMRA }\end{array}$ & $125 \mathrm{bp}$ & M57399 & pleiotropin \\
\hline B2M & $\begin{array}{c}\text { (+) ACCCCCACTGAAAAAGATGAGT } \\
(-) \text { GGCATCTTCAAACCTCCATGA } \\
\text { FAM-AGTCACATGGTTCACACGGCAGGCA-TAMRA }\end{array}$ & $117 \mathrm{bp}$ & M17986 & $\beta 2$ microglobulin \\
\hline PPIA & $\begin{array}{c}\text { (+) GTCAACCCCACCGTGTTCTT } \\
(-) \text { CTGCTGTCTTTGGGACCTTGT } \\
\text { FAM-AGCTCAAAGGAGACGCGGCCCA-TAMRA }\end{array}$ & 97 bp & Y00052 & cyclophilin A \\
\hline SOD-1 & $\begin{array}{c}\text { (+) CTGAAGGCCTGCATGGATTC } \\
\text { (-) CCAAGTCTCCAACATGCCTCTC } \\
\text { FAM- TCATCCTTTGGCCCACCGTGTTT -TAMRA }\end{array}$ & $138 \mathrm{pb}$ & X02317 & $\begin{array}{c}\text { CuZn superoxide } \\
\text { dismutase }\end{array}$ \\
\hline
\end{tabular}



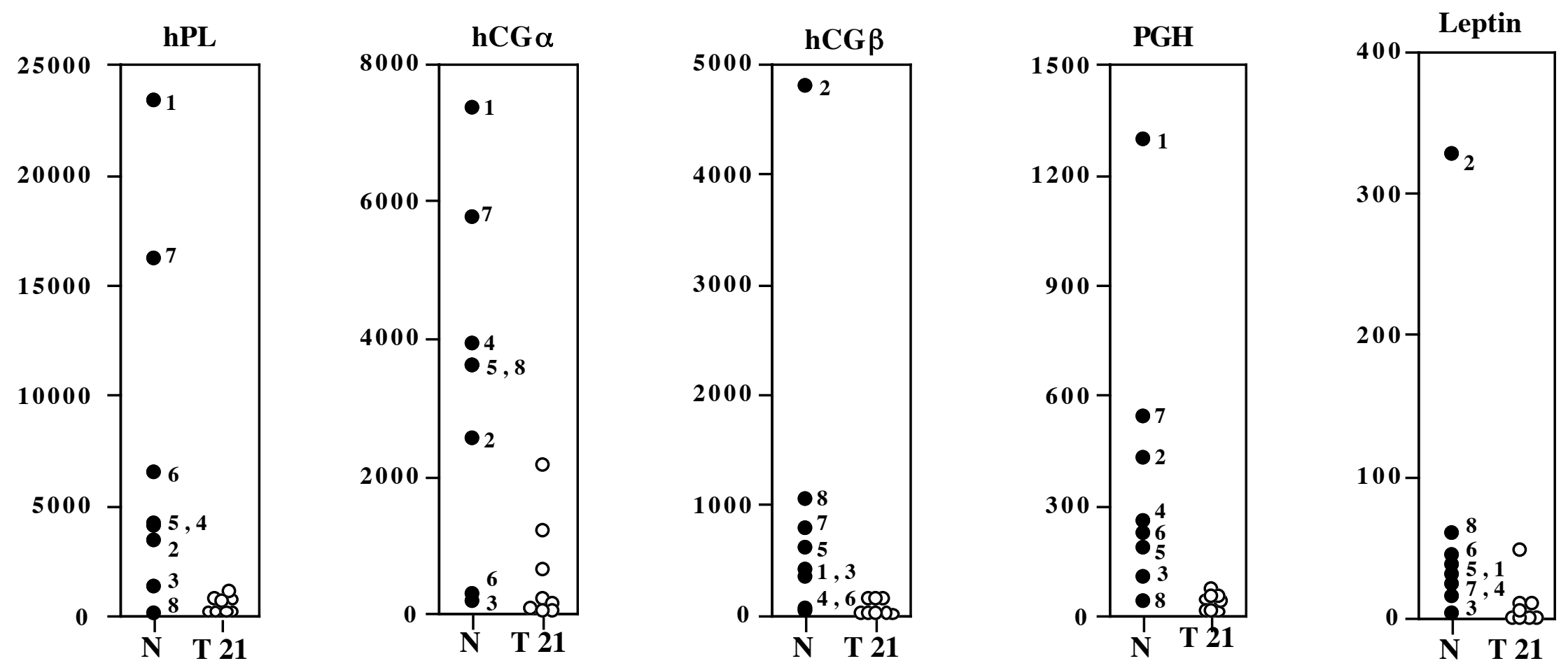

\begin{tabular}{|c|c|c|c|c|c|c|c|c|c|c|}
\hline & \multicolumn{2}{|c|}{ hPL } & \multicolumn{2}{|c|}{ hCG $\alpha$} & \multicolumn{2}{|c|}{ hCG $\beta$} & \multicolumn{2}{|c|}{ PGH } & \multicolumn{2}{|c|}{ Leptin } \\
\hline & $\mathbf{N}$ & T 21 & $\mathbf{N}$ & T 21 & $\mathbf{N}$ & T 21 & $\mathbf{N}$ & T 21 & $\mathbf{N}$ & T 21 \\
\hline mean & 7424 & 503 & 3401 & 567 & 1012 & 59 & 386 & 36 & 68 & 9.5 \\
\hline SEM & \pm 7606 & \pm 400 & \pm 2294 & \pm 710 & \pm 1463 & \pm 63 & \pm 377 & $\pm \mathbf{3 0}$ & \pm 99 & \pm 15 \\
\hline $\mathbf{p}$ & \multicolumn{2}{|c|}{0.0087} & \multicolumn{2}{|c|}{0.0087} & \multicolumn{2}{|c|}{0.0063} & \multicolumn{2}{|c|}{0.0016} & \multicolumn{2}{|c|}{0.0116} \\
\hline
\end{tabular}

